\title{
Ixodid ticks (Acari: Ixodidae) collected from African savanna elephants (Loxodonta africana) and African forest elephants (Loxodonta cyclotis)
}

\begin{tabular}{|c|c|}
\hline \multicolumn{2}{|c|}{$\begin{array}{l}\text { Authors: } \\
\text { Edward Kariuki }{ }^{1,2} \\
\text { Hellen Kutima } \\
\text { Michael Kock } \\
\text { Ivan G. Horak }^{5} \\
\text { Roaland Jooste }^{6} \\
\text { Luis Neves }^{5}\end{array}$} \\
\hline \multicolumn{2}{|c|}{$\begin{array}{l}\text { Affiliations: } \\
{ }^{1} \text { Department of Veterinary } \\
\text { Services, Kenya Wildlife } \\
\text { Service, Nairobi, Kenya }\end{array}$} \\
\hline \multicolumn{2}{|c|}{$\begin{array}{l}{ }^{2} \text { School of Biomedical } \\
\text { Sciences, Jomo Kenyatta } \\
\text { University of Agriculture and } \\
\text { Technology, Nairobi, Kenya }\end{array}$} \\
\hline \multicolumn{2}{|c|}{$\begin{array}{l}{ }^{3} \text { Department of Zoology, } \\
\text { Jomo Kenyatta University of } \\
\text { Agriculture and Technology, } \\
\text { Nairobi, Kenya }\end{array}$} \\
\hline \multicolumn{2}{|c|}{$\begin{array}{l}{ }^{4} \text { International Wildlife } \\
\text { Veterinary Services, } \\
\text { Greyton, South Africa }\end{array}$} \\
\hline \multicolumn{2}{|c|}{$\begin{array}{l}{ }^{5} \text { Department of Veterinary } \\
\text { Tropical Diseases, Faculty of } \\
\text { Veterinary Science, University } \\
\text { of Pretoria, Pretoria, } \\
\text { South Africa }\end{array}$} \\
\hline \multicolumn{2}{|c|}{$\begin{array}{l}{ }^{6} \text { Animal Health Division, } \\
\text { Bayer (Pty) Ltd, Isando, } \\
\text { Johannesburg, South Africa }\end{array}$} \\
\hline \multicolumn{2}{|c|}{$\begin{array}{l}\text { Corresponding author: } \\
\text { Luis Neves, } \\
\text { Ineves17@gmail.com }\end{array}$} \\
\hline \multicolumn{2}{|c|}{$\begin{array}{l}\text { Dates: } \\
\text { Received: } 18 \text { Apr. } 2019 \\
\text { Accepted: } 15 \text { July } 2019 \\
\text { Published: } 06 \text { Nov. } 2019\end{array}$} \\
\hline \multicolumn{2}{|l|}{ Read online: } \\
\hline astar & $\begin{array}{l}\text { Scan this QR } \\
\text { code with your } \\
\text { smart phone or } \\
\text { mobile device } \\
\text { to read online. }\end{array}$ \\
\hline
\end{tabular}

Eight ixodid tick species were collected from 173 African savanna elephants (Loxodonta africana) in Kenya, northern Mozambique and Zimbabwe, and two species were collected from six African forest elephants (Loxodonta cyclotis) in the Republic of Congo. A new host record is reported for Amblyomma eburneum. A list of ticks collected from elephants in various African countries, and stored in the United States National Tick Collection, is supplied as well as an annotated checklist of the 27 ixodid tick species that have been collected from African elephants. The geographic distributions and alternative hosts of the various tick species collected from elephants are briefly discussed.

Keywords: African savanna elephants; African forest elephants; ixodid ticks; Republic of Congo; Kenya.

\section{Introduction}

Despite the African savanna elephants' iconic status, no surveys dedicated to the ticks of elephants as such have been conducted in Africa. Hoogstraal (1956) recorded collections of Amblyomma tholloni from four elephants in the Equatoria province, Sudan, and Theiler (1962) reported collections of eight Amblyomma spp. (two are doubtful records) from elephants in sub-Saharan Africa. Among these, $A$. tholloni was present in 18 countries from Sierra Leone and Sudan in the north to South Africa in the south. Theiler also reported collections of Dermacentor circumguttatus from elephants in 10 countries in West, Central and East Africa, from Sierra Leone in the west to Tanzania in the east and northern Mozambique in the south. Furthermore, she recorded the collection of 10 Rhipicephalus spp. from elephants, among which were three of the four ornate Rhipicephalus spp.: Rhipicephalus humeralis, Rhipicephalus maculatus and Rhipicephalus pulchellus. Unfortunately, Theiler did not record the number of elephants infested with each species. Yeoman and Walker (1967) reported collections from 19 elephants in Tanzania along with collections made from numerous other animals, including domestic livestock. The elephants were infested with four tick species and 16 animals were infested with $A$. tholloni, three with D. circumguttatus and four with Rhipicephalus maculatus. In Kenya, Walker (1974) recorded eight tick species in collections made from 78 elephants. Forty-four animals were infested with A. tholloni, 28 with R. humeralis, 12 with R. maculatus and nine with Rhipicephalus praetextatus (then referred to as Rhipicephalus simus). In addition to A. tholloni and R. maculatus, Baker and Keep (1970) included Rhipicephalus appendiculatus, Rhipicephalus muehlensi and R. simus in a checklist of the ticks found on elephants and other large wildlife species in the north-eastern reserves of KwaZulu-Natal, South Africa. Amblyomma tholloni was the only species in collections made from 29 elephants in Zimbabwe (Norval 1983). Including the above-mentioned Rhipicephalus species, Walker, Keirans and Horak (2000) list 15 Rhipicephalus species that have been collected from elephants, among which is the fourth ornate Rhipicephalus species, R. dux. In a review of the ticks of the Central African Republic, Uilenberg, Estrada-Peña and Thal (2013) recorded a number of historic as well as recent collections of Amblyomma astrion, Amblyomma cohaerens, A. tholloni, Amblyomma variegatum, D. circumguttatus and Rhipicephalus longus from elephants. In Namibia, 8 of 45 elephants examined in the Etosha National Park harboured only Hyalomma truncatum, while no ticks were collected from the remaining elephants (Turner et al. 2017). In South Africa, Horak et al. (2018) recorded 32 collections from elephants, of which one animal was infested with a solitary Amblyomma hebraeum female, 23 with A. tholloni and eight with $R$. maculatus.

How to cite this article: Kariuki, E., Kutima, H., Kock, M., Horak, I.G., Jooste, R. \& Neves, L., 2019, 'Ixodid ticks (Acari: Ixodidae) collected from African savanna elephants (Loxodonta africana) and African forest elephants (Loxodonta cyclotis)', Onderstepoort Journal of Veterinary Research 86(1), a1781. https://doi.org/10.4102/ojvr.v86i1.1781

Copyright: ( 2019. The Authors. Licensee: AOSIS. This work is licensed under the Creative Commons Attribution License. 
Here, we report opportunistic collections made since 1988 from African savanna elephants in Kenya, northern Mozambique and Zimbabwe and from African forest elephants in the Republic of Congo. We also include a list of tick species collected from elephants and deposited in the United States National Tick Collection (USNTC) as well as an annotated checklist of the tick species collected to date from African elephants.

\section{Methods}

The management or translocation of elephants usually necessitates that they are restrained by sedation. Between 1988 and 2019, ticks were collected opportunistically from 173 sedated African savanna elephants and six African forest elephants. The animals were examined visually and ticks removed both manually and by using forceps. The ticks from each elephant were placed in individually labelled vials containing $70 \%$ ethanol and transported to the laboratory, where they were identified under a stereoscopic microscope using conventional keys and descriptions. No total collections of ticks were made from any of the elephants because of the size of the animal, the shortage of workforce, difficult operating conditions and the usually short period between sedation and resuscitation. The countries of origin and the species and number of ticks collected have been summarised in tabular format.

\section{Ethical considerations}

The Kenyatta University Ethics Review Committee (KU-ERC) reviewed and approved the study protocol. The National Commission for Science, Technology and Innovation (NACOSTI) and the Kenya Wildlife Service (KWS) authorised the field study in Kenya.

\section{Results}

The number of elephants examined in Kenya, Mozambique, Zimbabwe and the Democratic Republic of Congo, and the species and number of ticks collected are summarised in Table 1.

A total of 128 elephants were examined at 61 localities across Kenya and 1964 ticks were collected (Table 1). The adults of eight tick species were identified in the collections. Two species belonged to the genus Amblyomma and six to the genus Rhipicephalus. Amblyomma tholloni was the most prevalent species and was collected from $88.3 \%$ of the elephants. Amblyomma eburneum is the first record of this species for African elephants. Three ornate species of Rhipicephalus are present in Kenya: $R$. humeralis, $R$. maculatus and R. pulchellus (Walker et al. 2000), and all were collected from the elephants. Ticks were also collected from a sick elephant in the Shimba Hills National Reserve, Kenya. It was infested with large numbers of ticks, and more than 3000 $R$. maculatus, as well as some A. tholloni, were collected from the posterior surface of a single ear.
TABLE 1: Species and number of ticks collected from savanna and forest elephants.

\begin{tabular}{|c|c|c|c|}
\hline \multirow[t]{2}{*}{ Country or tick species } & \multirow{2}{*}{$\begin{array}{l}\text { Number } \\
\text { infested }\end{array}$} & \multicolumn{2}{|c|}{ Number of ticks collected } \\
\hline & & Male & Female \\
\hline \multicolumn{4}{|l|}{ Kenya $(n=128)$} \\
\hline Amblyomma eburneum & 1 & 9 & 4 \\
\hline Amblyomma tholloni & 113 & 894 & 375 \\
\hline Rhipicephalus appendiculatus & 3 & 3 & 0 \\
\hline Rhipicephalus compositus & 1 & 4 & 1 \\
\hline Rhipicephalus humeralis & 18 & 353 & 121 \\
\hline Rhipicephalus maculatus & 7 & 30 & 17 \\
\hline Rhipicephalus praetextatus & 11 & 12 & 8 \\
\hline Rhipicephalus pulchellus & 7 & 77 & 43 \\
\hline \multicolumn{4}{|l|}{ Mozambique $(n=36)$} \\
\hline Amblyomma tholloni & 36 & 147 & 61 \\
\hline Rhipicephalus maculatus & 8 & 5 & 4 \\
\hline \multicolumn{4}{|l|}{ Zimbabwe $(n=9)$} \\
\hline Amblyomma tholloni & 9 & 66 & 24 \\
\hline \multicolumn{4}{|c|}{ Democratic Republic of Congo $(n=6 \dagger)$} \\
\hline Amblyomma tholloni & 6 & 27 & 31 \\
\hline Dermacentor circumguttatus & 5 & 10 & 10 \\
\hline
\end{tabular}

$n=$ number of elephants sampled.

$\dagger$, forest elephants.

Amblyomma tholloni was collected from all 36 elephants sampled in the Reserva Nacional do Niassa, Niassa Province, Mozambique, and $R$. maculatus was present in eight of these animals (Table 1). The nine animals sampled in Zimbabwe were infested only with $A$. tholloni. Six forest elephants examined in the Odzala-Kokoua National Park, Republic of Congo, were all infested with $A$. tholloni, while D. circumguttatus was collected from five animals (Table 1).

The species present in historic collections of ticks from African elephants between 1905 and 1980 and deposited in the USNTC are listed in Table 2.

Ticks from elephants in 14 African countries were present in the USNTC. Amblyomma tholloni was collected from elephants in 10 countries, D. circumguttatus in five, $R$. praetextatus (as R. simus) in three and R. maculatus in two. Rhipicephalus humeralis was collected from two elephants in Kenya, Amblyomma cohaerens from a single animal in Uganda and $R$. pravus from a single animal in Somalia.

An annotated checklist of tick species recorded on African elephants is presented in Table 3.

A total of 27 ixodid tick species have been collected from African elephants, and eight Amblyomma species, 16 Rhipicephalus species as well as D. circumguttatus, D. rhinocerinus and Hyalomma truncatum have been reported.

\section{Discussion}

The discussion will focus on the tick species collected in the current survey.

\section{Amblyomma species}

Amblyomma eburneum is a relatively rare species. Yeoman and Walker (1967) recorded it in the Eastern Province, Tanzania, 
TABLE 2: Ticks collected from African elephants (1905-1980) and deposited in the United States National Tick Collection.

\begin{tabular}{|c|c|c|c|}
\hline \multirow[t]{2}{*}{ Country or tick species } & \multirow{2}{*}{$\begin{array}{l}\text { Number of } \\
\text { collections }\end{array}$} & \multicolumn{2}{|c|}{ Number of ticks collected } \\
\hline & & Male & Female \\
\hline \multicolumn{4}{|l|}{ Sierra Leone } \\
\hline Amblyomma tholloni & 1 & 16 & 14 \\
\hline Dermacentor circumguttatus & 1 & 2 & 1 \\
\hline \multicolumn{4}{|l|}{ Ghana } \\
\hline Dermacentor circumguttatus & 1 & 10 & 6 \\
\hline \multicolumn{4}{|l|}{ Nigeria } \\
\hline Amblyomma tholloni & 1 & 2 & 1 \\
\hline \multicolumn{4}{|l|}{ Cameroon } \\
\hline Dermacentor circumguttatus & 1 & 2 & 2 \\
\hline \multicolumn{4}{|l|}{ Republic of Congo } \\
\hline Dermacentor circumguttatus & 1 & 1 & 1 \\
\hline \multicolumn{4}{|l|}{ Democratic Republic of Congo } \\
\hline Amblyomma tholloni & 1 & 0 & 2 \\
\hline \multicolumn{4}{|l|}{ Angola } \\
\hline Amblyomma tholloni & 2 & 10 & 2 \\
\hline \multicolumn{4}{|l|}{ Somalia } \\
\hline Amblyomma tholloni & 1 & 1 & 0 \\
\hline Rhipicephalus praetextatus & 1 & 1 & 1 \\
\hline Rhipicephalus pravus & 1 & 1 & 0 \\
\hline \multicolumn{4}{|l|}{ Sudan } \\
\hline Amblyomma tholloni & 5 & 12 & 7 \\
\hline Rhipicephalus praetextatus & 7 & 36 & 49 \\
\hline \multicolumn{4}{|l|}{ Kenya } \\
\hline Amblyomma tholloni & 6 & 100 & 11 \\
\hline Rhipicephalus humeralis & 2 & 6 & 6 \\
\hline Rhipicephalus maculatus & 8 & 286 & 343 \\
\hline \multicolumn{4}{|l|}{ Uganda } \\
\hline Amblyomma cohaerens & 1 & 3 & 2 \\
\hline Amblyomma tholloni & 16 & 76 & 62 \\
\hline Dermacentor circumguttatus & 11 & 35 & 13 \\
\hline Rhipicephalus praetextatus & 2 & 7 & 5 \\
\hline \multicolumn{4}{|l|}{ Tanzania } \\
\hline Rhipicephalus maculatus & 1 & 10 & 10 \\
\hline \multicolumn{4}{|l|}{ Malawi } \\
\hline Amblyomma tholloni & 1 & 2 & 1 \\
\hline \multicolumn{4}{|l|}{ Mozambique } \\
\hline Amblyomma tholloni & 2 & 2 & 2 \\
\hline \multicolumn{4}{|l|}{ Zimbabwe } \\
\hline Amblyomma tholloni & 3 & 5 & 7 \\
\hline
\end{tabular}

while according to Walker (1974), 'The few records of A. eburneum in Kenya are widely scattered', where it has been found mainly in the centre and south of the country. Here, we report the first record on the African elephant. Collections have, however, been made from buffaloes in Tanzania (Yeoman \& Walker 1967), cattle, black rhinoceroses, buffaloes, an oryx and a warthog in Kenya (Walker 1974), and buffaloes in Mozambique (Dias 1993).

Amblyomma tholloni was present in the majority of collections made from elephants in Kenya and Tanzania as well as in all the collections made from these animals in Zimbabwe (Norval 1983; Walker 1974; Yeoman \& Walker 1967). The collection of A. tholloni from elephants in Kenya, the Republic of Congo, northern Mozambique and Zimbabwe in the present study confirms its widespread geographical distribution on African elephants. In Zimbabwe, however, Norval (1983) recorded $A$. tholloni on 22 of 24 hippopotamuses from which ticks had been
TABLE 3: Annotated checklist of the tick species collected from African elephants.

\begin{tabular}{|c|c|c|}
\hline No & Tick & References \\
\hline 1 & Amblyomma astrion & Theiler (1962); Uilenberg et al. (2013) \\
\hline 2 & Amblyomma cohaerens & Theiler (1962); Matthysse and Colbo (1987) \\
\hline 3 & Amblyomma eburneum & Kariuki et al. (present article) \\
\hline 4 & Amblyomma gemma & Theiler (1962) \\
\hline 5 & Amblyomma hebraeum & Horak et al. (2018) \\
\hline 6 & Amblyomma sparsum & Theiler (1962); Walker (1974) \\
\hline 7 & Amblyomma tholloni & $\begin{array}{l}\text { Hoogstraal (1956); Aeschlimann (1967); } \\
\text { Yeoman and Walker (1967); Baker and Keep } \\
\text { (1970); Walker (1974); Uilenberg et al. (2013); } \\
\text { Kariuki et al. (present article) }\end{array}$ \\
\hline 8 & Amblyomma variegatum & Theiler (1962); Uilenberg et al. (2013) \\
\hline 9 & Dermacentor circumguttatus & $\begin{array}{l}\text { Theiler (1962); Aeschlimann (1967); Yeoman } \\
\text { and Walker (1967); Uilenberg et al. (2013); } \\
\text { Kariuki et al. (present article) }\end{array}$ \\
\hline 10 & Dermacentor rhinocerinus & Theiler (1962) \\
\hline 11 & Hyalomma truncatum & Turner et al. (2017); Horak et al. (2018) \\
\hline 12 & Rhipicephalus appendiculatus & $\begin{array}{l}\text { Theiler (1962); Baker and Keep (1970); Walker } \\
\text { et al. (2000); Kariuki et al. (present article) }\end{array}$ \\
\hline 13 & Rhipicephalus compositus & Theiler (1962); Kariuki et al. (present article) \\
\hline 14 & Rhipicephalus dux & Walker et al. (2000) \\
\hline 15 & Rhipicephalus evertsi evertsi & Walker (1974); Walker et al. (2000) \\
\hline 16 & Rhipicephalus humeralis & $\begin{array}{l}\text { Theiler (1962); Walker (1974); Walker et al. } \\
\text { (2000); Kariuki et al. (present article) }\end{array}$ \\
\hline 17 & Rhipicephalus kochi & Walker et al. (2000) \\
\hline 18 & Rhipicephalus longus & $\begin{array}{l}\text { Theiler (1962); Walker et al. (2000); Uilenberg } \\
\text { et al. (2013) }\end{array}$ \\
\hline 19 & Rhipicephalus maculatus & $\begin{array}{l}\text { Theiler (1962); Yeoman and Walker (1967); } \\
\text { Baker and Keep (1970); Walker (1974); Walker } \\
\text { et al. (2000); Kariuki et al. (present article) }\end{array}$ \\
\hline 20 & Rhipicephalus muehlensi & $\begin{array}{l}\text { Theiler (1962); Baker and Keep (1970); Walker } \\
\text { et al. (2000) }\end{array}$ \\
\hline 21 & Rhipicephalus planus & Walker et al. (2000) \\
\hline 22 & Rhipicephalus praetextatus & $\begin{array}{l}\text { Walker et al. (2000); Fyumagwa et al. (2007); } \\
\text { Kariuki et al. (present article) }\end{array}$ \\
\hline 23 & Rhipicephalus pravus & $\begin{array}{l}\text { Theiler (1962); Walker (1974); Walker et al. } \\
(2000)\end{array}$ \\
\hline 24 & Rhipicephalus pulchellus & $\begin{array}{l}\text { Theiler (1962); Walker (1974); Walker et al. } \\
\text { (2000); Kariuki et al. (present article) }\end{array}$ \\
\hline 25 & Rhipicephalus senegalensis & Theiler (1962); Walker et al. (2000) \\
\hline 26 & Rhipicephalus simus & $\begin{array}{l}\text { Theiler (1962); Baker and Keep (1970); Walker } \\
\text { et al. (2000) }\end{array}$ \\
\hline 27 & Rhipicephalus ziemanni & Walker et al. (2000) \\
\hline
\end{tabular}

collected. One of the two hippopotamuses we examined in Kenya was infested with $A$. tholloni. Ticks were collected from the inside of the lips, the nostrils, an ear and the skinfolds of the neck of this hippopotamus.

MacKenzie and Norval (1980) demonstrated that A. tholloni could transmit Ehrlichia ruminatium, the causative organism of heartwater in cattle, sheep and goats in the laboratory. They also noted that cattle, sheep and goats at a research station within a nature reserve in the Zambezi Valley were often infested with the immature stages of $A$. tholloni and that cases of heartwater occurred in these animals in the absence of any of the other known tick vectors.

\section{Dermacentor circumguttatus}

Hoogstraal (1956) regarded D. circumguttatus as an elephant tick and reported that it was present on these animals in West and Central Africa, extending in the east only to the western regions of Uganda and Sudan. However, Yeoman and Walker (1967) reported it in elephants in the far north-western corner of Tanzania where it borders Uganda. Dias (1993) 
reported 10 males and two females of a subspecies that he referred to as D. circumguttatus cunhasilvai from elephants in the Mossurize region of Manica Province, Mozambique. Dermacentor circumguttatus has not been collected from this locality since then, nor were any of the elephants examined in the present study in the Reserva Nacional do Niassa, Mozambique, infested with it.

\section{Rhipicephalus species}

We believe that the occurrence of $R$. appendiculatus on elephants represents an unusual infestation. Rhipicephalus compositus, of which a single collection was made, has been collected from thick-skinned animals, rhinoceroses, warthogs, bush pigs and buffaloes. While a large number of collections have also been made from cattle, the occurrence of this species on an elephant should be regarded as rare (Walker et al. 2000).

Rhipicephalus humeralis is an ornate Rhipicephalus species and is only present in mainland Tanzania, Kenya and Somalia (Walker et al. 2000). In Kenya, it occurs in the coastal region and bushed and wooded grassland in the south and central regions. Walker (1974) recorded 16 collections from cattle, 28 from elephants and nine from black rhinoceroses in Kenya, with one or two collections from other domestic and wild animals. Rhipicephalus maculatus is present in coastal woodland and bush and adjacent inland from north-eastern KwaZulu-Natal to southern Somalia (Walker et al. 2000). In addition to the coastal regions of Kenya, Tanzania and Mozambique, it is also present in bushed and wooded grassland in south and central Kenya as well as in woodland and bush adjacent to the coastal regions of Mozambique and Tanzania (Walker et al. 2000). It is a large ornate species with stout mouthparts and has been collected from hosts with thick hides: elephants, white and black rhinoceroses, bush pigs and buffaloes (Baker \& Keep 1970; Horak et al. 1983, 2017; Horak, Boomker \& Flamand 1991; Kariuki et al. 2012).

Rhipicephalus praetextatus is present in central and southern Ethiopia and northern Somalia (Walker et al. 2000). Ticks originally identified as $R$. simus and now presumed to be $R$. praetextatus have been recorded in southern Somalia, and practically throughout Kenya and Tanzania (Walker et al. 2000). Walker et al. (2000) reported 12 collections of $R$. praetextatus (species unconfirmed) from elephants in East Africa, and it has subsequently been collected from elephants in the Ngorongoro Crater, Tanzania (Fyumagwa et al. 2007). In the current study, $R$. praetextatus was collected from 11 elephants.

Rhipicephalus pulchellus is widespread in Eritrea, eastern Ethiopia, Somalia, east of the Great Rift Valley in Kenya and north-eastern Tanzania (Walker et al. 2000). Kariuki et al. (2012) collected R. pulchellus from cattle and sympatric buffaloes in south-eastern Kenya. This ornate tick species infests a multitude of domestic and wild animals among which Walker et al. (2000) reported three African elephants. Seven elephants in our study were infested with R. pulchellus. Although Rhipicephalus dux was not collected in the present survey, Walker et al. (2000) have recorded its presence on elephants. It is found in the Democratic Republic of Congo, particularly in the north-east, in Rwanda and in northwestern Uganda (Matthysse \& Colbo 1987). Thus, the four ornate Rhipicephalus spp. have all been collected from elephants.

\section{Acknowledgements}

The authors thank the Kenya Wildlife Service and the National Research Fund, Kenya, for providing resources used for the field work. A grant from the National Research Foundation (NRF) to I.G. Horak made it possible to sponsor the visits of E.K. Kariuki to South Africa. Edward Kariuki thanks friends and veterinary students for assistance with collecting ticks.

\section{Competing interests}

The authors declare that they have no financial or personal interests that may have inappropriately influenced them in writing this article.

\section{Authors' contributions}

All authors read and approved the manuscript. The first draft of the manuscript was prepared by E.K., I.G.H. and L.N. E.K., H.K., M.K. R.J. collected the ticks and E.K., H.K., L.N. and I.G.H. identified them.

\section{Funding information}

This study was financially supported by the Kenya Wildlife Service and the National Research Foundation (NRF) of South Africa grant to I.G. Horak.

\section{Data availability statement}

Data sharing is not applicable to this article as no new data were created or analysed in this study.

\section{Disclaimer}

Any opinion, finding and conclusion or recommendation expressed in this article are those of the authors and do not necessarily reflect the official policy or position of any affiliated agency of the authors.

\section{References}

Aeschlimann, A., 1967, 'Biologie et écologie des tiques (Ixodoidea) de Côte d'Ivoire', Acta Tropica 24, 281-405.

Baker, M.K. \& Keep, M.E., 1970, 'Checklist of the ticks found on the larger game animals in the Natal game reserves', Lammergeyer 12, 41-47.

Dias, J.A.T.S., 1993, 'Some data concerning the ticks (Acarina-Ixodoidea) presently known in Mozambique', Garcia de Orta, Séries Zoologica, Lisboa 18(1/2), 27-48.

Fyumagwa, R.D., Runyoro, V., Horak, I.G. \& Hoare, R., 2007, 'Ecology and control of ticks as disease vectors in wildlife of the Ngorongoro Crater, Tanzania', South African Journal of Wildlife Research 37(1), 79-90. https://doi.org/10.3957/03794369-37.1.79

Hoogstraal, H., 1956, African Ixodoidea. I. Ticks of the Sudan (with special reference to Equatoria Province and with preliminary reviews of the genera Boophilus, Department of the Navy Bureau of Medicine and Surgery, Washington, DC. 
Horak, I.G., Boomker, J. \& Flamand, J.R.B., 1991, 'Ixodid ticks and lice infesting red duikers and bushpigs in north-eastern Natal', Onderstepoort Journal of Veterinary Research 58(1), 281-284

Horak, I.G., Boshoff, C.R., Cooper, D.V., Foggin, C.M., Govender, D., Harrison, A. et al., 2017, 'Parasites of domestic and wild animals in South Africa. XLIX. Ticks (Acari: Ixodidae) infesting white and black rhinoceroses in Southern Africa', Onderstepoort Journal of Veterinary Research 84(1), e1-e11. https://doi.org/10.4102/ojvr. vournal of

Horak, I.G., Heyne, H., Williams, R., Gallivan, G.J., Spickett, A.M., Bezuidenhout, J.D. \& Estrada-Peña, A., 2018, The ticks (Acari: Ixodidae) of Southern Africa, Springer International Publishing AG, Basel, Switzerland.

Horak, I.G., Potgieter, F.T., Walker, J.B., De Vos, V. \& Boomker, J., 1983, 'The ixodid tick burdens of various large ruminant species in South African nature reserves', Onderstepoort Journal of Veterinary Research 50, 221-228.

Kariuki, E.K., Penzhorn B.L., Horak I.G., 2012, 'Ticks (Acari: Ixodidae) infesting cattle and African buffaloes in the Tsavo Conservation Area, Kenya', Onderstepoort Journal of Veterinary Research 79(1), 437-440 https://doi.org/10.4102/ojvr. v79i1.437

MacKenzie, P.K.I. \& Norval, R.A.I., 1980, 'The transmission of Cowdria ruminantium by Amblyomma tholloni', Veterinary Parasitology 7(3), 265-268. https://doi.org/ 10.1016/0304-4017(80)90030-8
Matthysse, J.G. \& Colbo, M.H., 1987, The ixodid ticks of Uganda, p. 426, Entomological Society of America, College Park, MD.

Norval, R.A.I., 1983, 'The ticks of Zimbabwe. VII. The genus Amblyomma', Zimbabwe Veterinary Journal 14, 3-18.

Theiler, G., 1962, The Ixodoidea parasites of vertebrates in Africa south of the Sahara (Ethiopian region), p. 260, Project S 9958, Report to the Director of Veterinary Services, Onderstepoort (mimeographed).

Turner, W.C., Küsters, M., Versfeld, W. \& Horak, I.G., 2017, 'Ixodid tick diversity on wild mammals, birds and reptiles in and around Etosha National Park, Namibia', African Journal of Ecology 55(4), 714-721. https://doi.org/10.1111/aje.12369

Uilenberg, G., Estrada-Peña, A. \& Thal, J., 2013, 'Ticks of the Central African Republic', Experimental and Applied Acarology 60(1), 1-40. https://doi.org/10.1007/ s10493-012-9605-2

Walker, J.B., 1974, The ixodid ticks of Kenya: A review of present knowledge of their hosts and distribution, Commonwealth Institute of Entomology, London.

Walker, J.B., Keirans, J.E. \& Horak, I.G., 2000, The genus Rhipicephalus (Acari, Ixodidae): A guide to the brown ticks of the world, Cambridge University Press, Cambridge.

Yeoman, G.H. \& Walker, J.B., 1967, The ixodid ticks of Tanzania. A study of the zoogeography of the Ixodidae of an east African country, Commonwealth Institute of Entomology, London. 